\title{
PIGMEN RUMPUT LAUT MERAH (Acanthophora spicifera) SEBAGAI ALTERNATIF PEWARNA ALAMI PADA PRODUK SOSIS IKAN LELE DUMBO (Clarias gariepinus)
}

\section{SEAWEED RED PIGMENT(Acanthophora spicifera) AS AN ALTERNATIVE IN PRODUCING NATURAL DYES OF CATFISH (Clarias gariepinus) SAUSAGE PRODUC}

\author{
Yiyik Windah Yulianti ${ }^{1}$, Moch. Amin Alamsjah ${ }^{2}$ dan Riesta P.H. ${ }^{3}$ \\ ${ }^{1}$ Sekolah Pascasarjana Universitas Airlangga \\ Kampus B J1. Airlangga 4-6 Surabaya, 60286 Telp. 031-5041566 \\ ${ }^{2}$ Fakultas Perikanan dan Kelautan Universitas Airlangga \\ Kampus C Mulyorejo - Surabaya, 60115 Telp. 031-5911451 \\ ${ }^{3}$ Fakultas Farmasi Universitas Airlangga \\ Kampus C Mulyorejo - Surabaya, 60115
}

\begin{abstract}
Aquatic resources that have great potential to be developed is a pigment obtained from seaweed. According Winarno (1996), seaweeds are clasified into three classes, namely red algae (Rhodophyceae), brown algae (Phaeophyceae) and green algae (Chlorophyceae). There are three main types of pigment in the seaweed, namely: chlorophyll, carotenoids, and phycocyanin (Lila, 2004). Each type of pigment that provides different benefits to human life. Red seaweed spicifera types Acanthophora be extracted and taken the pigment has a branch color (thallus) are varied, due to the pigment composition consisting of chlorophyll a, chlorophyll d, and fikobiliprotein (R-phycocyanin, allofikosianin and fikoeritrin) (Lee, 2008). Fikoeritrin is the dominant pigment in red algae, thus giving the appearance of red on the thallus.

The use of pigments is very important not only in the food and beverages, but also in medicines, cosmetics and pharmaceutical industrial. It is one of the determinants of consumer acceptance of products offered. Source of pigments used are also used by consumers as one of the indicators in assessing the quality of a product. The use of natural or synthetic dyes in the product will enhance the visual appeal that will increase consumer preference for products offered, therefore, the use of natural dye for industrial cannot be avoided.

Based on the description above, this study will extract the pigment from red algae (A.spicifera) with a polar solvent (ethanol, distilled water) which will be used as a dye in catfish sausage with different proportions and determine the color stability during storage at cold temperatures and using the analytical method for determining the wavelength spectrophotometer fikoeritrin extraction results.

The aim of the study is getting the appropriate method to produce the red pigment of seaweed $A$. spicifera, obtain the pigmen concentrate that can be applied to the catfish sausage and determine the stability of the color pigment $A$. spicifera on application of catfish sausages during storage.

The study consisted of two examination to obtain the best dose of A. spicifera pigmen. The first step is to find wavelength of fikoeritrin. The design of the study is completely randomized design RAK with 12 treatmens and 3 replications.

The results of the study showed that the red pigmen A. spicifera can be used as a dye in catfish sausage with the best concentration of $0.75 \%$. Concentration and storage time catfish sausage significant effect on the intensity of reddish and yellowish color, but not significantly different to the intensity of brightness and water content. The concentration of pigment A. spicifera different in catfish sausage on organoleptic test gives a significant difference in color, smell and flavor
\end{abstract}

Keywords : pigment, concentration, stability

\section{Pendahuluan}

Rumput laut dengan spesies beraneka ragam di Indonesia mempunyai potensi nilai tambah yang sangat tinggi dan mempunyai pigmen yang sangat bermanfaat bagi kehidupan, namun sampai saat ini belum banyak dilakukan penelitian. Selama ini, negara Indonesia masih mengimpor pigmen alami dari Tiongkok maupun Amerika. Menurut Limantara dan Heriyanto (2010) bahwa rumput laut coklat yang mengandung pigmen fukoxanthin setelah dihasilkan pigmen, maka harganya menjadi 20.000.000 kali lebih tinggi. Mengingat potensinya yang demikian besar, maka pemerintah Indonesia, telah menjadikan rumput 
laut sebagai salah satu komoditi unggulan program revitalisasi kelautan.

Menurut Winarno (1992) pewarna alami tidak mengandung bahan yang berbahaya bagi kesehatan yang mengkonsumsinya. Berdasarkan kenyataan tersebut maka penggunaan pewarna alami sangat dianjurkan pada berbagai kebutuhan hidup manusia. Tingginya kebutuhan pewarna alami dalam kehidupan tersebut menuntut dilakukannya berbagai penelitian dari berbagai sumber biota alam yang dapat menghasilkan pigmen alam dengan harga yang terjangkau.

Sumberdaya perairan yang mempunyai potensi besar untuk dikembangkan adalah pigmen yang diperoleh dari rumput laut. Rumput laut merah jenis Acanthophora spicifera yang akan diekstraksi dan diambil pigmennya mempunyai warna cabang (thallus) yang bervariasi, disebabkan adanya komposisi pigmen yang terdiri dari klorofil a, klorofil d, dan fikobiliprotein ( $R$-fikosianin, allofikosianin serta fikoeritrin) (Lee, 2008). Fikoeritrin merupakan pigmen dominan pada alga merah, sehingga memberikan kenampakan merah pada thallus.

Pemakaian pigmen dalam industri makanan dan minuman, serta pada industri obat- obatan, kosmetika dan farmasi memberikan pengaruh yang sangat penting karena merupakan salah satu faktor penentu penerimaan konsumen terhadap produk yang ditawarkan. Sumber pigmen yang dipergunakan juga dipakai oleh konsumen sebagai salah satu indikator dalam menilai mutu suatu produk.

Berdasarkan rumusan masalah tersebut, maka tujuan dari penelitian ini adalah untuk mendapatkan metode yang tepat untuk menghasilkan pigmen merah dari rumput laut $A$. spicifera, mendapatkan konsentrasi pigmen yang tepat dapat diaplikasikan pada sosis ikan lele dumbo serta mengetahui stabilitas warna pigmen $A$. spicifera pada aplikasi sosis ikan lele dumbo selama masa penyimpanan.

\section{Materi dan Metode}

Tempat dan Waktu Penelitian

$$
\text { Penelitian ini dilakukan di }
$$

Laboratorium Agroekoteknologi, Ilmu Kelautan Universitas Trunojoyo, Laboratorium ULP dan Laboratorium Fakultas Farmasi Universitas Airlangga pada bulan Oktober 2014 - Januari 2015

Materi Penelitian

Peralatan Penelitian

Peralatan yang dipergunakan dalam pembuatan pigmen dan sosis ikan lele dumbo adalah : panci besar, timbangan, pisau, gunting, talenan, timbangan, kompor, gelas ukur, pengaduk, stuffler, food processor, cassing dan benang ikat sosis.

Peralatan laboratorium dalam penelitian yang dipergunakan adalah : bermacam-macam alat gelas, kertas saring whatman no. 41, thermometer, spektrofotometer UV-Vis, Utrasonik (Elma), Rotary evaporator (Buchi R-210), freeze drying christ (Beta 1-8 $\mathrm{K}$ ), timbangan digital, pipet , color reader CR10 (Minolta Co.Ltd., Jepang), kulkas dan lainlain.

\section{Bahan Penelitian}

Bahan baku yang dipergunakan dalam penelitian ini adalah rumput laut jenis $A$. spicifera dewasa yang tumbuh di pinggir pantai dan karang, diambil dari daerah pulau Kangean Kabupaten Sumenep. Setelah diambil, kemudian rumput laut dibawa menggunakan polyback dan ditaruh pada coolbox atau sterofoam yang telah diberi es batu, hal tersebut dimaksudkan untuk mencegah kerusakan pigmen karena cahaya maupun kenaikan suhu.

\section{Rancangan Penelitian}

Penelitian pendahuluan bertujuan untuk mendapatkan pigmen merah dari $A$. spicifera dengan metode yang tepat yang dibuktikan dengan pengukuran panjang gelombang mempergunakan spektrofotometer UV-vis.

Penelitian utama, setelah diperoleh metode yang tepat dengan menghasilkan panjang gelombang pigmen yang sesuai, kemudian pigmen yang diperoleh diaplikasikan pada sosis ikan lele dumbo yang bertujuan untuk mengetahui faktor $\mathrm{K}$ adalah konsentrasi (\%) dan faktor $\mathrm{H}$ adalah lama penyimpanan (hari) terhadap stabilitas warna sosis ikan lele dumbo pada penyimpanan suhu dingin. Penelitian utama memakai Rancangan Acak Kelompok (RAK) dengan 12 perlakuan, yaitu sosis ikan lele dumbo tanpa penambahan pigmen A. spicifera penyimpanan 1 hari $(\mathrm{K} 0 \mathrm{H} 1)$, penyimpanan 5 hari $(\mathrm{K} 0 \mathrm{H} 5)$ dan penyimpanan 10 hari (KOH10). Sosis ikan lele dumbo dengan penambahan pigmen $0,50 \%$ dengan penyimpanan 1 hari (K1H1), penyimpanan 5 hari (K1H5) dan penyimpanan 10 hari (K1H10). Sosis ikan lele dumbo dengan penambahan pigmen $0,75 \%$ dengan penyimpanan 1 hari (K2H1), penyimpanan 5 hari (K2H5) dan penyimpanan 10 hari (K2H10). Sosis ikan lele dumbo dengan penambahan pigmen $0,100 \%$ dengan penyimpanan 1 hari (K3H1), penyimpanan 5 hari (K2H5) dan penyimpanan 10 hari (K3H10). Masing-masing 
perlakuan diulang 3 kali sehingga didapat 36 perlakuan.

Analisis Data

- Analisa optimasi fikoeritrin pigmen rumput laut $A$. spicifera dengan menggunakan spektrofotometer UVvisible light (Shimadzu, Kyoto).

- Perhitungan perkiraan kadar fikoeritrin dalam 1 gram pigmen dengan rumus :

Total mg fikoeritrin =

$\underline{\mathrm{OD}}$ at $566 \mathrm{~nm} \mathrm{X}$ volume (in $\mathrm{ml}$ ) exstract

$$
8.20
$$

- Analisis kadar air metode oven vakum.

- Analisa intensitas warna dengan metode L*a*b* Twinter menggunakan color reader (Yuwono dan Susanto, 1998).

- Uji organoleptik meliputi bau, warna dan rasa (Rahayu, 2001).

- Perhitungan perlakuan terbaik (De Garmo, Sullivan dan Canada, 1984)

Data penelitian dianalisis secara statistik dengan Analisa Varian menggunakan Rancangan Acak Kelompok (RAK). Pengukuran pada percobaan penelitian menggunakan perbandingan konsentrasi pigmen pada produk sosis ikan, yaitu : $0 \%$ (A); 0,5\% (B); $0,75 \%$ dan (C); $1 \%$ yang terdapat 12 perlakuan dan diulang 3 kali. Data pengolahan dilakukan pada hasil penelitian dengan membuat tabel dan mencari kondisi yang optimum dari variabel-variabel yang ditetapkan.

\section{Hasil dan Pembahasan}

Pada penelitian utama, setelah diperoleh pigmen kering $A$. spicifera kemudian dilakukan spektrofotometer dengan pelarut aquadest. Gambar 6 memperlihatkan bahwa panjang gelombang maksimal pigmen merah A.spicifera berada pada kisaran $560-585 \mathrm{~nm}$, dengan puncaknya berada pada panjang gelombang $566 \mathrm{~nm}$.

Berdasarkan panjang gelombang yang diperoleh pada spektrofotometer diatas, maka diperkirakan kadar fikoeritrin dalam 1 gram pigmen adalah sebagai berikut :

Total $\mathrm{mg}$ fikoeritrin $=$

$$
\begin{aligned}
& \text { OD . at } 566 \mathrm{~nm} \mathrm{X} \text { volume (in ml) exstract } \\
& \begin{aligned}
8.20 \\
=\frac{0,52 \times}{8,20} \\
=6,3 \mathrm{mg}
\end{aligned}
\end{aligned}
$$

Hasil uji color reader kecerahan pada produk sosis ikan lele dumbo yang telah di beri pigmen merah $A$. spicifera adalah seperti pada Tabel 3.

Rerata nilai warna kecerahan pada berbagai kombinasi konsentrasi pigmen $A$. spicifera dan lama penyimpanan sosis ikan lele dumbo berkisar antara 5,6-7,1. Sedangkan perlakuan konsentrasi pigmen merah $A$. spicifera dan interaksi antara kedua perlakuan menunjukkan pengaruh tidak berbeda nyata terhadap nilai warna kecerahan pigmen merah A. spicifera $(\alpha=0,05)$.

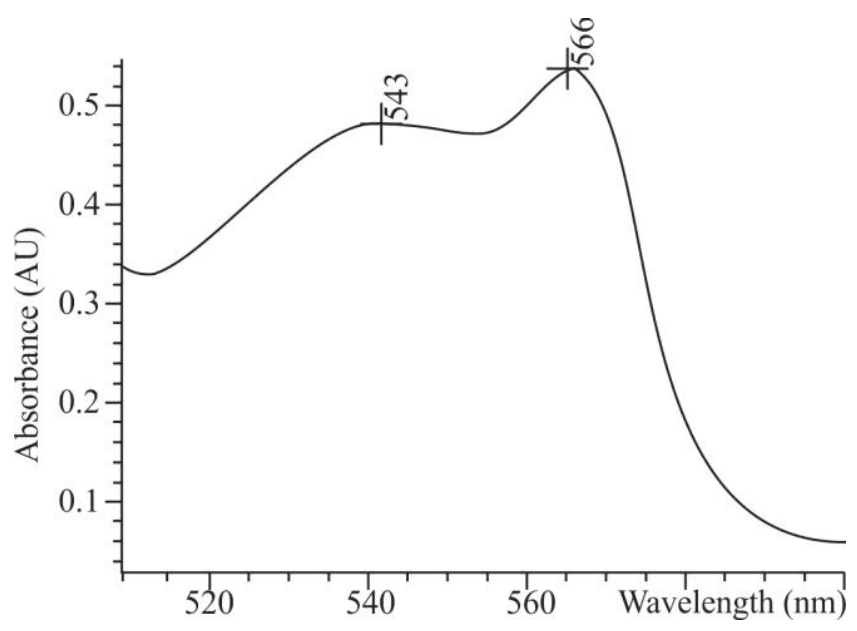

Gambar 6. Panjang gelombang pigmen Acanthophora spicifera dengan pelarut aquadest 
Tabel 3. Rerata Warna Kecerahan Sosis Ikan Lele Dumbo Akibat Pengaruh Konsentrasi Pigmen Merah Acanthophora spicifera dan Lama Penyimpanan

\begin{tabular}{|c|c|c|}
\hline \multicolumn{2}{|c|}{ Perlakuan } & \multirow{4}{*}{$\begin{array}{l}\text { Rata-Rata } \\
\text { Warna } \\
\text { Kecerahan }\end{array}$} \\
\hline Konsentrasi & Lama & \\
\hline Pigmen & Penyimpanan & \\
\hline$(\%)$ & (hari) & \\
\hline \multirow[t]{3}{*}{ K0 (0) } & $\mathrm{H} 1$ & $71,1^{\mathrm{a}}$ \\
\hline & H5 & $66,4^{\mathrm{a}}$ \\
\hline & $\mathrm{H} 10$ & $68,1^{\mathrm{a}}$ \\
\hline \multirow[t]{3}{*}{$\mathrm{K} 1(0,5)$} & $\mathrm{H} 1$ & $59,3^{\mathrm{b}}$ \\
\hline & H5 & $61,5^{\mathrm{b}}$ \\
\hline & $\mathrm{H} 10$ & $63,9^{\mathrm{b}}$ \\
\hline \multirow[t]{3}{*}{ K2 $(0,75)$} & $\mathrm{H} 1$ & $65,4^{b}$ \\
\hline & H5 & $59,2^{\mathrm{b}}$ \\
\hline & $\mathrm{H} 10$ & $61,8^{\mathrm{b}}$ \\
\hline \multirow[t]{3}{*}{ K3 (1) } & $\mathrm{H} 1$ & $61,9^{\mathrm{b}}$ \\
\hline & H5 & $60,0^{\mathrm{b}}$ \\
\hline & $\mathrm{H} 10$ & $56,6^{\mathrm{b}}$ \\
\hline Keterangan : & $\begin{array}{l}\text { Angka pada } \\
\text { superscript berb } \\
\text { beda nyata pa } \\
(\alpha=0,05)\end{array}$ & $\begin{array}{l}\text { olom deng } \\
\text { a menyatak } \\
\text { uji DMl }\end{array}$ \\
\hline
\end{tabular}

Hasil uji color reader intensitas warna kemerahan pada produk sosis ikan lele dumbo yang telah di beri pigmen merah A. spicifera adalah sebagai berikut :

Tabel 4. Rerata Warna Kemerahan Sosis Ikan Lele Dumbo Akibat Pengaruh Konsentrasi Pigmen Merah Acanthophora spicifera dan Lama Penyimpanan

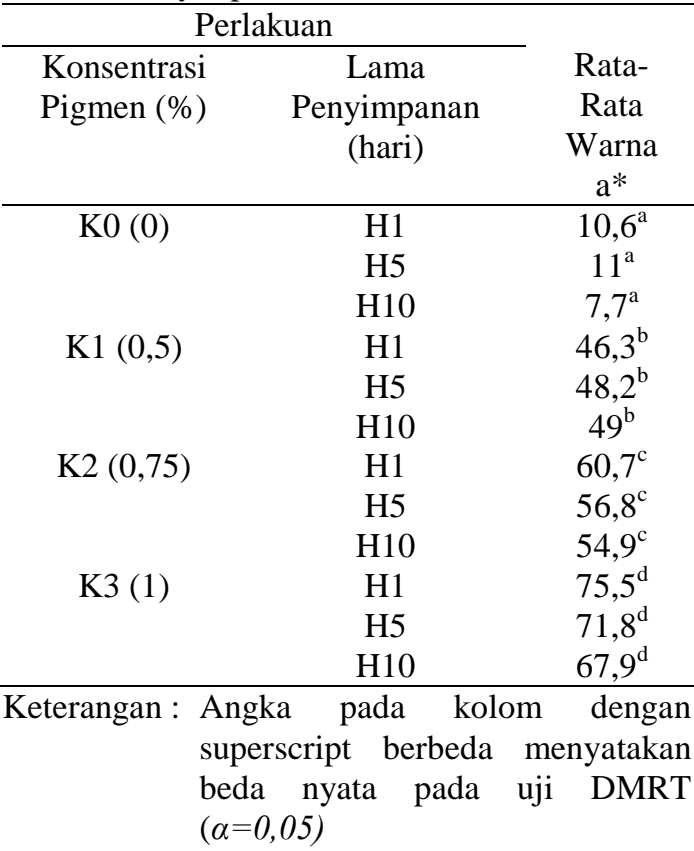

Perlakuan konsentrasi pigmen merah A. spicifera dan interaksi antara kedua perlakuan menunjukkan pengaruh sangat nyata terhadap nilai warna kemerahan sosis ikan lele dumbo $(\alpha=0,05)$. Pada tabel tersebut diperlihatkan bahwa rerata warna kemerahan sosis ikan lele dumbo terendah pada kontrol lama penyimpanan 1 hari dan rerata tertinggi pada perlakuan $0,100 \%$ pada penyimpanan 1 hari. Intensitas warna kemerahan pigmen merah A. spicifera akan meningkat seiring dengan penambahan pigmen merah $A$. spicifera.

Hasil uji color reader warna kekuningan pada produk sosis ikan lele dumbo yang telah di beri pigmen merah A. spicifera adalah sebagai berikut :

Tabel 5. Rerata Warna Kekuningan Sosis Ikan Lele Dumbo Akibat Pengaruh Konsentrasi Pigmen Merah Acanthophora. spicifera dan Lama Penyimpanan

\begin{tabular}{|c|c|c|}
\hline \multicolumn{2}{|c|}{ Perlakuan } & \multirow{4}{*}{$\begin{array}{c}\text { Rata-Rata } \\
\text { Warna } \\
\text { Kekuningan }\end{array}$} \\
\hline Konsentrasi & Lama & \\
\hline \multirow[t]{2}{*}{ Pigmen (\%) } & Penyimpanan & \\
\hline & (hari) & \\
\hline \multirow[t]{3}{*}{ K0 (0) } & $\mathrm{H} 1$ & $62,1^{\mathrm{a}}$ \\
\hline & H5 & $51,3^{\mathrm{a}}$ \\
\hline & $\mathrm{H} 10$ & $48,2^{\mathrm{a}}$ \\
\hline \multirow[t]{3}{*}{ K1 $(0,5)$} & $\mathrm{H} 1$ & $37^{\mathrm{b}}$ \\
\hline & H5 & $35^{\mathrm{b}}$ \\
\hline & $\mathrm{H} 10$ & $35,4^{\mathrm{b}}$ \\
\hline \multirow[t]{3}{*}{$\mathrm{K} 2(0,75)$} & $\mathrm{H} 1$ & $36,3^{b c}$ \\
\hline & $\mathrm{H} 5$ & $26,9^{\mathrm{bc}}$ \\
\hline & $\mathrm{H} 10$ & $28,4^{\mathrm{bc}}$ \\
\hline \multirow[t]{3}{*}{$\mathrm{K} 3$ (1) } & $\mathrm{H} 1$ & $29,6^{\mathrm{c}}$ \\
\hline & H5 & $28,1^{\mathrm{c}}$ \\
\hline & H10 & $26,3^{c}$ \\
\hline Keterangan & $\begin{array}{l}\text { Angka pada k } \\
\text { superscript }\end{array}$ & $\begin{array}{r}\text { om dengan } \\
\text { berbeda }\end{array}$ \\
\hline & $\begin{array}{l}\text { menyatakan be } \\
\text { uji DMRT }(\alpha=0\end{array}$ & nyata pada \\
\hline
\end{tabular}

Rerata nilai warna kekuningan pada berbagai konsentrasi pigmen merah $A$. spicifera dan lama penyimpanan sosis ikan lele dumbo berkisar antara 26,1 - 62,1. Perlakuan konsentrasi dan interaksi kedua perlakuan menunjukkan pengaruh nyata terhadap nilai warna kekuningan sosis ikan lele dumbo $(\alpha=$ $0,05)$. Pengaruh perbedaan konsentrasi pigmen merah A. spicifera dan lama penyimpanan terhadap nilai warna kekuningan dengan bertambahnya proporsi rata-rata intensitas warna kekuningan semakin berkurang. 
Kadar air sosis ikan lele dumbo yang telah diberi pigmen $A$. spicifera dengan proporsi yang berbeda, adalah sebagai berikut :

Tabel 6. Rerata Kadar Air Sosis Ikan Lele Dumbo Akibat Pengaruh Konsentrasi Pigmen Merah Acanthophora spicifera dan Lama Penyimpanan

\begin{tabular}{|c|c|c|}
\hline \multicolumn{2}{|c|}{ Perlakuan } & \multirow{3}{*}{$\begin{array}{l}\text { Rata-Rata } \\
\text { Kadar Air } \\
\quad(\%)\end{array}$} \\
\hline Konsentrasi & Lama & \\
\hline Pigmen (\%) & $\begin{array}{l}\text { Penyimpanan } \\
\text { (hari) }\end{array}$ & \\
\hline \multirow[t]{3}{*}{ K0 (0) } & $\mathrm{H} 1$ & $77,05^{\mathrm{a}}$ \\
\hline & H5 & $91,47^{\mathrm{a}}$ \\
\hline & H10 & $55,06^{\mathrm{a}}$ \\
\hline \multirow[t]{3}{*}{$\mathrm{K} 1(0,5)$} & $\mathrm{H} 1$ & $54,67^{\mathrm{a}}$ \\
\hline & H5 & $84,63^{\mathrm{a}}$ \\
\hline & $\mathrm{H} 10$ & $64,18^{\mathrm{a}}$ \\
\hline \multirow[t]{3}{*}{ K2 $(0,75)$} & $\mathrm{H} 1$ & $76,77^{\mathrm{a}}$ \\
\hline & $\mathrm{H} 5$ & $76,99^{\mathrm{a}}$ \\
\hline & $\mathrm{H} 10$ & $77,80^{\mathrm{a}}$ \\
\hline \multirow[t]{3}{*}{ K3 (1) } & $\mathrm{H} 1$ & $68,72^{\mathrm{a}}$ \\
\hline & H5 & $72,17^{\mathrm{a}}$ \\
\hline & H10 & $90,76^{\mathrm{a}}$ \\
\hline \multicolumn{3}{|c|}{$\begin{aligned} \text { Keterangan : } & \text { Angka pada kolom dengan } \\
& \text { superscript berbeda menyatakan } \\
& \text { beda nyata pada uji DMRT } \\
& (\alpha=0,05)\end{aligned}$} \\
\hline
\end{tabular}

Tabel 6. Menunjukkan rerata kadar air sosis ikan lele dumbo terendah pada konsentrasi $0,50 \%$ dengan penyimpanan 1 hari, yaitu 54,67 dan tertinggi adalah konsentrasi $0 \%$ pada penyimpanan 5 hari yaitu 91,47. Lama penyimpanan sosis ikan lele dumbo cenderung memiliki kadar air yang meningkat namun masih stabil, hal tersebut dibuktikan dengan kadar air sosis ikan lele dumbo selama penyimpanan tidak menunjukkan perbedaan yang signifikan.

Hasil uji organoleptik warna dengan skala hedonik 1-5 (suka-sangat tidak suka) sosis ikan lele dumbo yang diberi pigmen $A$. spicifera dengan proporsi yang berbeda dapat dilihat pada Tabel 7.

Hasil skor uji organoleptik terhadap warna sosis ikan lele dumbo berkisar antara 1,5$3,5 \quad(\alpha=0,05), \quad$ sedangkan total rangking penilaian panelis terhadap warna dari sosis ikan lele dumbo berkisar antara 3,2 - 4,7. Hasil uji lanjut Friedman pada Lampiran 15 terhadap tingkat kesukaan panelis pada warna sosis ikan lele dumbo akibat pengaruh konsentrasi pigmen merah A. spicifera berbeda memberikan hasil signifikan $(\alpha=0,05)$.
Tabel 7. Total Rangking Nilai Kesukaan Warna Sosis Ikan Lele Dumbo karena Konsentrasi Pigmen Merah Acanthophora spicifera dan Lama Penyimpanan Yang Berbeda

\begin{tabular}{|c|c|c|}
\hline \multicolumn{2}{|c|}{ Perlakuan } & \multirow{4}{*}{$\begin{array}{c}\text { Total } \\
\text { Rangking } \\
\text { Kesukaan } \\
\text { warna }\end{array}$} \\
\hline Konsentrasi & Lama & \\
\hline Pigmen $(\%)$ & Penyimpanan & \\
\hline & (hari) & \\
\hline \multirow[t]{3}{*}{0} & 1 & 3.7 \\
\hline & 5 & 3.4 \\
\hline & 10 & 3.2 \\
\hline \multirow[t]{3}{*}{0,50} & 1 & 4.1 \\
\hline & 5 & 3.8 \\
\hline & 10 & 3.8 \\
\hline \multirow[t]{3}{*}{0,75} & 1 & 4.7 \\
\hline & 5 & 4.6 \\
\hline & 10 & 4.4 \\
\hline \multirow[t]{3}{*}{0,100} & 1 & 4.3 \\
\hline & 5 & 4 \\
\hline & 10 & 3,8 \\
\hline
\end{tabular}

Hasil uji organoleptik aroma dengan skala hedonik 1-5 (suka-sangat tidak suka) sosis ikan lele dumbo yang diberi pigmen $A$. spicifera dengan proporsi yang berbeda dapat dilihat pada Tabel 8.

Hasil skor uji organoleptik terhadap aroma sosis ikan lele dumbo berkisar antara 1,7$3,6 \quad(\alpha=0,05)$, sedangkan total rangking penilaian panelis terhadap aroma dari sosis ikan lele dumbo berkisar antara 3,3-4,5. Hasil uji lanjut Friedman pada Lampiran 15 terhadap tingkat kesukaan panelis pada aroma sosis ikan lele dumbo akibat pengaruh konsentrasi pigmen merah A. spicifera berbeda memberikan hasil signifikan $(\alpha=0,05)$.

Tabel 8. Total Rangking Nilai Kesukaan Aroma Sosis Ikan Lele Dumbo karena Konsentrasi Pigmen Merah Achanthophora spicifera dan Lama Penyimpanan Yang Berbeda

\begin{tabular}{|c|c|c|}
\hline \multicolumn{2}{|c|}{ Perlakuan } & \multirow{5}{*}{$\begin{array}{c}\text { Total } \\
\text { Rangking } \\
\text { Kesukaan } \\
\text { Aroma }\end{array}$} \\
\hline Konsentrasi & Lama & \\
\hline Pigmen (\%) & Penyimpanan & \\
\hline & (hari) & \\
\hline & & \\
\hline \multirow[t]{3}{*}{0} & 1 & 3.7 \\
\hline & 5 & 3.7 \\
\hline & 10 & 3.5 \\
\hline \multirow[t]{3}{*}{0,50} & 1 & 4.5 \\
\hline & 5 & 4.4 \\
\hline & 10 & 4.1 \\
\hline \multirow[t]{3}{*}{0,75} & 1 & 4.4 \\
\hline & 5 & 3.8 \\
\hline & 10 & 3.7 \\
\hline \multirow[t]{3}{*}{0,100} & 1 & 3.7 \\
\hline & 5 & 3.3 \\
\hline & 10 & 3.3 \\
\hline
\end{tabular}


Hasil uji organoleptik rasa dengan skala hedonik 1-5 (suka-sangat tidak suka) sosis ikan lele dumbo yang diberi pigmen $A$. spicifera dengan proporsi yang berbeda dapat dilihat pada Tabel 9.

Tabel 9. Total Rangking Nilai Kesukaan Rasa Sosis Ikan Lele Dumbo karena Konsentrasi Pigmen Merah Achanthophora spicifera dan Lama Penyimpanan Yang Berbeda

\begin{tabular}{ccc}
\hline \multicolumn{2}{c}{ Perlakuan } & \\
\cline { 1 - 2 } Konsentrasi & $\begin{array}{c}\text { Lama } \\
\text { Potal } \\
\text { Penyimpanan } \\
\text { (hari) }\end{array}$ & $\begin{array}{c}\text { Rangking } \\
\text { Kesukaan } \\
\text { Rasa }\end{array}$ \\
\hline 0 & 1 & 3.8 \\
& 5 & 3.8 \\
0,50 & 10 & 3.5 \\
& 1 & 4.4 \\
0,75 & 5 & 4.3 \\
& 10 & 3.9 \\
0,100 & 1 & 4.3 \\
& 5 & 3.8 \\
& 10 & 3.6 \\
& 1 & 3.7 \\
& 5 & 3.6 \\
\hline
\end{tabular}

Hasil skor uji organoleptik terhadap rasa sosis ikan lele dumbo berkisar antara 1,8$3,4 \quad(\alpha=0,05)$, sedangkan total rangking penilaian panelis terhadap rasa dari sosis ikan lele dumbo berkisar antara 3,3-4,4. Hasil uji lanjut Friedman pada Lampiran 15 terhadap tingkat kesukaan panelis pada rasa sosis ikan lele dumbo akibat pengaruh konsentrasi pigmen merah $A$. spicifera berbeda memberikan hasil signifikan $(\alpha=0,05)$.

Hasil penelitian utama, memperoleh pigmen dengan tampilan warna merah. Pigmen yang diperoleh kemudian dianalisis dengan spectrofotometer dengan puncak panjang gelombang yang diperoleh $566 \mathrm{~nm}$ yang merupakan panjang gelombang fikoeritrin. Warna pigmen merah tersebut sangat cocok diaplikasikan pada produk yang menginginkan penampakan warna merah seperti sosis

Penurunan intensitas warna kecerahan disebabkan oleh penambahan konsentrasi pigmen merah $A$. spicifera dari $0,100 \%, 0,75 \%$ dan $0,50 \%$. Penambahan konsentrasi pigmen merah A. spicifera menyebabkan intensitas warna menurun karena sosis ikan lele dumbo akan semakin berwarna merah dan menyebabkan turunnya nilai intensitas warna kecerahan. Menurut teori (Ameny and Wilson, 1997; Knoll, 2005), kecerahan merupakan spektrum warna dasar, adanya penambahan warna lain pada suatu obyek akan menurunkan nilai kecerahan.

Pada penelitian ini lama penyimpanan dan konsentrasi tidak memberikan pengaruh nyata terhadap warna pigmen merah $A$. spicifera. Pigmen merah A. spicifera yang ditambahkan sebagai pewarna pada sosis ikan lele dumbo cenderung mempunyai warna yang stabil selama masa penyimpanan. Hal tersebut dapat diketahui dari perubahan rerata intensitas warna kecerahan pigmen merah A. spicifera selama masa penyimpanan cenderung menurun, namun tidak menunjukkan perbedaan yang signifikan.

Menurut Lawless and Heyman (1998) dalam Satriyanto (2012), bahwa axis a* menunjukkan intensitas warna merah $(+)$ dan hijau (-). Rerata intensitas warna kemerahan pada berbagai kombinasi konsentrasi pigmen merah A. spicifera dan lama penyimpanan sosis ikan lele dumbo berkisar antara 7,7 - 75,5. Perlakuan konsentrasi pigmen merah $A$. spicifera dan interaksi antara kedua perlakuan menunjukkan pengaruh sangat nyata terhadap nilai warna intensitas warna kemerahan sosis ikan lele dumbo $(\alpha=0,05)$. Penambahan pigmen merah $A$. spicifera pada produk sosis ikan lele dumbo akan meningkatkan intensitas warna kemerahan.

Penambahan proporsi pigmen merah $A$. spicifera menyebabkan intensitas warna kekuningan meningkat. Peningkatan intensitas warna kekuningan pada sosis ikan lele dumbo diperkirakan adanya peningkatan senyawa karoten yang berwarna merah-orange. Menurut Eskin (1990), bahwa semakin tinggi kadar betakaroten makan akan menyebabkan semakin meningkat pula intensitas warna merah atau kuning.

Rerata kadar air sosis ikan lele dumbo pada berbagai proporsi dan lama penyimpanan berkisar antara 54,67 - 91,47. Hasil analisa ragam menunjukkan bahwa perlakuan perbedaan konsentrasi pigmen merah $A$. spicifera dan lama penyimpanan serta interaksi kedua perlakuan tidak berbeda nyata $(\alpha=0,05)$. Hal tersebut disebabkan karena kadar air pada setiap perlakuan sosis ikan lele dumbo adalah sama. Pigmen merah A. spicifera yang ditambahkan pada produk dalam bentuk kering meskipun dalam konsentrasi yang berbeda tidak akan mempengaruhi kadar air sosis ikan lele dumbo.

Pada penambahan proporsi pigmen merah A. spicifera yang berbeda akan memberikan respon yang berbeda pada panelis terhadap warna sosis ikan lele dumbo. Total 
rangking penilaian panelis terhadap warna dari sosis ikan lele dumbo berkisar antara 48-71 (Lampiran 13). Daya terima panelis terhadap warna sosis ikan lele dumbo meningkat seiring dengan bertambahnya proporsi pigmen merah A. spicifera sampai pada konsentrasi $0,75 \%$ dan kemudian menurun pada konsentrasi $0,100 \%$. Selama penyimpanan dengan bertambahnya waktu penyimpanan, penerimaan panelis terhadap warna sosis ikan lele dumbo cenderung menurun. Berdasarkan uji organoleptik terhadap warna, rangking terendah (panelis netral) memiliki skor 3,2 dengan total rangking 48 diperoleh pada konsentrasi $0 \%$ (kontrol) dan lama penyimpanan 10 hari. Sedangkan rangking tertinggi panelis (sangat suka) dengan skor 4,7 dengan total rangking 71 diperoleh pada konsentrasi $0,75 \%$ pada hari I.

Penambahan pewarna pada makanan akan menjadikan suatu produk makanan menjadi lebih menarik dan memberi rangsangan kepada konsumen untuk membeli. Dijelaskan oleh Nugraheni (2014), bahwa pewarna merupakan bahan yang ditambahkan dalam makanan yang berfungsi untuk memberikan warna yang khas dan menjadi ciri khusus dari suatu makanan.

B. Aroma

Daya terima panelis terhadap aroma sosis ikan lele dumbo meningkat seiring dengan bertambahnya proporsi pigmen merah $A$. spicifera sampai pada konsentrasi $0,50 \%$ dan kemudian mulai menurun pada konsentrasi 0,75 $\%$. Selama penyimpanan dengan bertambahnya waktu penyimpanan, penerimaan panelis terhadap warna sosis ikan lele dumbo cenderung menurun. Berdasarkan uji organoleptik terhadap warna, rangking terendah (panelis netral) memiliki skor 3,27 dengan total rangking 49 diperoleh pada konsentrasi $0,100 \%$ (kontrol) dan lama penyimpanan 10 hari. Sedangkan rangking tertinggi panelis (sangat suka) dengan skor 4,47 dengan total rangking 67 diperoleh pada konsentrasi $0,50 \%$ pada hari I.

Penerimaan panelis terhadap rasa sosis ikan lele dumbo dengan bertambahnya waktu penyimpanan cenderung menurun. Berdasarkan uji organoleptik terhadap rasa, rangking terendah (panelis netral) memiliki skor 3,3 dengan total rangking 50 diperoleh pada konsentrasi $0,100 \%$ (kontrol) dan lama penyimpanan 10 hari. Sedangkan rangking tertinggi panelis (sangat suka) dengan skor 4,4 dengan total rangking 66 diperoleh pada konsentrasi $0,50 \%$ pada hari I.

Dengan bertambahnya proporsi pigmen pigmen A. spicifera pada sosis ikan lele dumbo akan meningkatkan rasa khas rumput laut yang cenderung berbau amis, sehingga sampai pada proporsi tertentu akan menurunkan nilai rasa sosis ikan lele dumbo.

\section{Kesimpulan}

Pigmen merah A. spicifera bisa dipakai sebagai pewarna pada sosis ikan lele dumbo dengan konsentrasi terbaik 0,75\%. Konsentrasi dan lama penyimpanan sosis ikan lele dumbo berpengaruh nyata terhadap intensitas warna kemerahan dan kekuningan, namun tidak berbeda nyata terhadap intensitas kecerahan dan kadar air. Konsentrasi pigmen $A$. spicifera yang berbeda pada sosis ikan lele dumbo terhadap uji organoleptik memberikan perbedaan signifikan pada warna, aroma dan rasa Perlu dilakukan penelitian lebih lanjut terhadap perlakuan suhu pemanasan pigmen $A$. spicifera terhadap kestabilan warna. Perlu dilakukan penelitian lebih lanjut mengenai potensi lain dari pigmen $A$. spicifera

\section{Daftar Pustaka}

De Garmo E.P., W.G. Sullivan dan J.R. Canada, 1984. Engineering Economy. Seventh Edition. Macmillan Publishing Company. New York.

Lee RE, 2008. Phycology. Ed ke-4 Cambridge : Cambridge University Press. 547 hal.

Limantara, L. dan Rahayu, P., 2007. Prospek Kesehatan Pigmen Alami. Prosiding Seminar Nasional Pigmen 2007 MB UKSW.Salatiga.ISBN.979-1098. 16-4.

Puji Rahayu dan Leenawaty Limantara, 2005. Studi Lapangan Kandungan Khlorofil in Vivo Beberapa Spesies Tumbuhan Hijau di Salatiga dan Sekitarnya. Seminar Nasional MIPA 2005.

Winarno, FG., 1992. Kimia Pangan dan Gizi. Jakarta. Gramedia Pustaka Utama.

Winarno, FG., 1996. Teknologi Pengolahan Rumput Laut. Pustaka Sinar Harapan. Jakarta. 